\title{
LONG-TERM STORAGE AND AERIAL TRANSPORT OF FROZEN MOUSE EMBRYOS
}

\author{
D. G. WHITTINGHAM AND W. K. WHITTEN \\ Physiological Laboratory, Cambridge CB2 3EG, England, and \\ Jackson Laboratory, Bar Harbor, Maine, U.S.A.
}

(Received 7th September 1973)

The first mammalian embryos to be successfully frozen and thawed were those of the mouse (Whittingham, 1971a; Whittingham, Leibo \& Mazur, 1972; Wilmut, 1972). Live young were obtained from mouse embryos which had been stored for up to 8 days at $-196^{\circ} \mathrm{C}$, after subsequent thawing and transfer to suitably prepared foster mothers (Whittingham et al., 1972). We now report the first successful transatlantic aerial shipment of two inbred strains of mice as frozen eight-cell embryos and their survival after storage for up to 8 months at $-196^{\circ} \mathrm{C}$.

Eight-cell mouse embryos were obtained from two inbred strains of mice $(\mathrm{C} 57 \mathrm{BL} / 6 \mathrm{~J} \times \mathrm{C} 57 \mathrm{BL} / 6 \mathrm{~J}$ and $\mathrm{BALB} / \mathrm{cWt} \times \mathrm{BALB} / \mathrm{cWt})$ at the Jackson Laboratory, Bar Harbor, Maine, U.S.A. They were flushed from the oviducts of naturally mated females on the morning of the second day after finding the coital plug. Embryos were collected in phosphate-buffered medium (Whittingham \& Wales, 1969) and after washing them free of débris, groups of ten to fifteen embryos were placed in freezing tubes in $0.1 \mathrm{ml}$ phosphate-buffered medium. The procedures for freezing and thawing the embryos have been described previously (Whittingham et al., 1972), cryoprotection was afforded by $1 \mathrm{M}$-dimethylsulphoxide (DMSO) added to the samples at $0^{\circ} \mathrm{C}$. The embryos were cooled from $0^{\circ} \mathrm{C}$ to $-110^{\circ} \mathrm{C}$ at rates ranging from $0.22^{\circ} \mathrm{C}$ to $1.0^{\circ} \mathrm{C} / \mathrm{min}$ and then transferred immediately to liquid nitrogen $\left(-196^{\circ} \mathrm{C}\right)$. They were warmed from $-110^{\circ} \mathrm{C}$ to $0^{\circ} \mathrm{C}$ at approximately $4^{\circ} \mathrm{C} / \mathrm{min}$.

Samples of each inbred strain were thawed after storing for 2 days at $-196^{\circ} \mathrm{C}$ and their viability was tested by culture in a modified Krebs-Ringer bicarbonate medium (Whittingham, 1971b) for a further $48 \mathrm{hr}$. Forty-eight $(100 \%)$ C57BL/6J and sixty-one $(93 \%)$ BALB/cWt embryos were recovered and forty-eight $(100 \%)$ and thirty-nine $(64 \%)$, respectively, developed into blastocysts during culture (Table 1). The difference in the survival rate of the two strains may not be real as the sample sizes were small. Alternatively, it may have been caused either by the increased sensitivity of the BALB $/ \mathrm{cWt}$ embryos to the freezing and thawing process or by variations in the protective action of DMSO. This point is under further investigation.

After approximately 7 months' storage in a liquid nitrogen refrigerator at the Jackson Laboratory, Maine, U.S.A., a total of sixty-four C57BL/6J and twenty-one BALB/cWt embryos were transported in a small liquid nitrogen canister by air from Bar Harbor to London and then by car to the Physiological 
Laboratory, Cambridge. Samples of both strains were thawed shortly after their arrival in Cambridge (189 days after freezing); thirty-eight $(100 \%)$ C57BL/6J embryos and ten $(90 \%)$ BALB/cWt embryos were recovered and thirty-five $(92 \%)$ and three $(30 \%)$, respectively, developed into blastocysts during culture (Table 1 and see also Pl. 1, Figs $1 \mathrm{a}, \mathrm{b}$ ). The high rate of survival of $\mathrm{C} 57 \mathrm{BL} / 6 \mathrm{~J}$ embryos to the blastocyst stage appeared to be unimpaired by storage at $-196^{\circ} \mathrm{C}(100 \%$ versus $92 \%)$. The survival of $\mathrm{BALB} / \mathrm{cWt}$ embryos was lower but the sample size was small.

Table 1. Viability of frozen eight-cell mouse embryos of two inbred strains after storage at $-196^{\circ} \mathrm{C}$ for up to 8 months and aerial transportation

\begin{tabular}{l|c|c|c|c|c|c|c}
\hline $\begin{array}{c}\text { Mouse } \\
\text { strain }\end{array}$ & $\begin{array}{c}\text { Length of } \\
\text { storage at } \\
-196^{\circ} \mathrm{C} \text { (days) }\end{array}$ & $\begin{array}{c}\text { No. of } \\
\text { embryos } \\
\text { frozen }\end{array}$ & $\begin{array}{c}\text { No. of } \\
\text { embryos } \\
\text { recovered }\end{array}$ & $\begin{array}{c}\text { No. of embryos } \\
\text { developing to } \\
\text { blastocysts } \\
\text { in vitro }\end{array}$ & $\begin{array}{c}\text { No. of blastocysts } \\
\text { transferred to } \\
\text { pseudopregnant } \\
\text { recipients }\end{array}$ & $\begin{array}{c}\text { No. of } \\
\text { fetuses }\end{array}$ & $\begin{array}{c}\text { No. of } \\
\text { liveborn }\end{array}$ \\
\hline G57BL/6J & 2 & 48 & 48 & 48 & - & - & - \\
Total & 189 & 38 & 38 & 35 & 35 & 11 & 5 \\
\hline BALB/cWt & 222 & 26 & 25 & 22 & 22 & 10 & 3 \\
& 112 & 111 & 105 & 57 & 21 & 8 \\
\hline Total & 22 & 66 & 61 & 39 & -3 & - & - \\
\hline
\end{tabular}

The blastocysts developing from both strains were transferred to pseudopregnant females-CFLP Carworth Europe-(three to six blastocysts/horn/ female) mated with vasectomized males (CFLP Carworth Europe) previously proven sterile; the techniques are described elsewhere (Biggers, Moore \& Whittingham, 1965). Thirty-five C57BL/6J blastocysts were transferred to the uterine horns of six pseudopregnant females; five females, killed on the 18th day of pregnancy, had eleven morphologically normal black-eyed fetuses from the twenty-nine blastocysts transferred $(38 \%)$ and one female gave birth to five normal black-eyed young at term from six blastocysts transferred (Table 1 and Pl. 2, Fig. 2). Three liveborn melanin-free young were obtained after transferring the three BALB/cWt blastocysts. Thus, a total of sixteen $\mathrm{C} 57 \mathrm{BL} / 6 \mathrm{~J}$ embryos ( $42 \%$ of those originally frozen) developed to full term fetuses and live young, and three BALB/cWt embryos $(27 \%)$ survived and developed into live young after storage for 189 days at $-196^{\circ} \mathrm{C}$.

The remainder of the transported embryos were thawed after 222 days storage at $-196^{\circ} \mathrm{C}$. Twenty-five $(96 \%) \mathrm{C} 57 \mathrm{BL} / 6 \mathrm{~J}$ and ten $(100 \%) \mathrm{BALB} / \mathrm{cWt}$ embryos were recovered after thawing and twenty-two $(88 \%)$ and five $(50 \%)$, respectively, developed into blastocysts during culture (Table 1). Twenty-two C57BL/6J blastocysts were transferred to four pseudopregnant recipients; three females, killed on the 18th day of pregnancy, had ten morphologically normal black-eyed fetuses out of the sixteen blastocysts transferred $(63 \%)$ and one female littered three normal C57BL/6J young at term from six blastocysts transferred (Table 1). Five $\mathrm{BALB} / \mathrm{cWt}$ blastocysts were transferred to one 


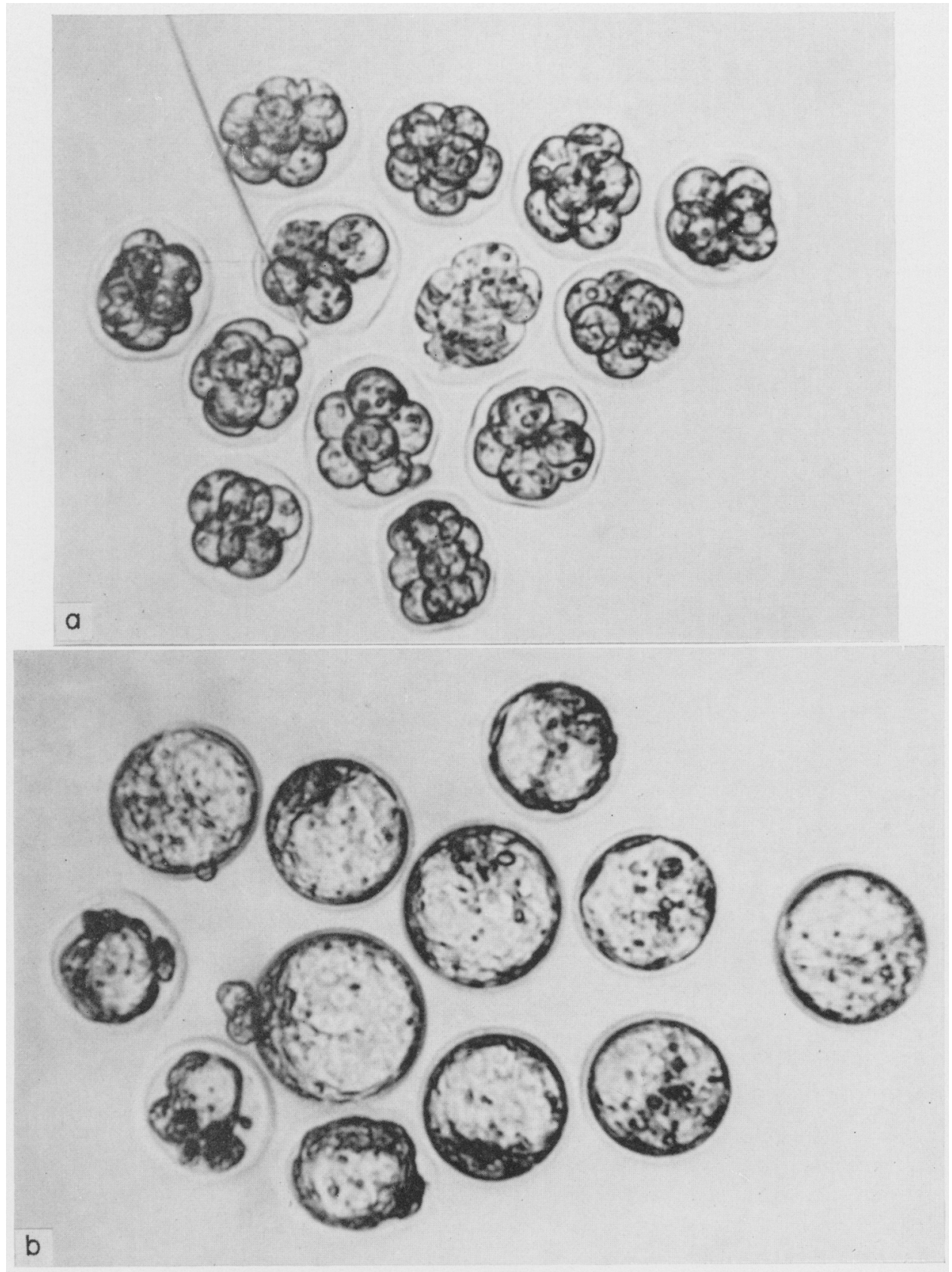

FIG. 1. (a) A group of thirteen eight-cell C57/BL/6J embryos thawed and recovered after storage at $-196^{\circ} \mathrm{C}$ for 189 days. $\times 125$. (b) A group of twelve eight-cell C57BL/6J embryos thawed after 222 days at $-196^{\circ} \mathrm{C}$ and then cultured in vitro for $36 \mathrm{hr}$. There are ten morphologically normal blastocysts and two small abnormal blastocysts with degenerated blastomeres. $\times 125$. 


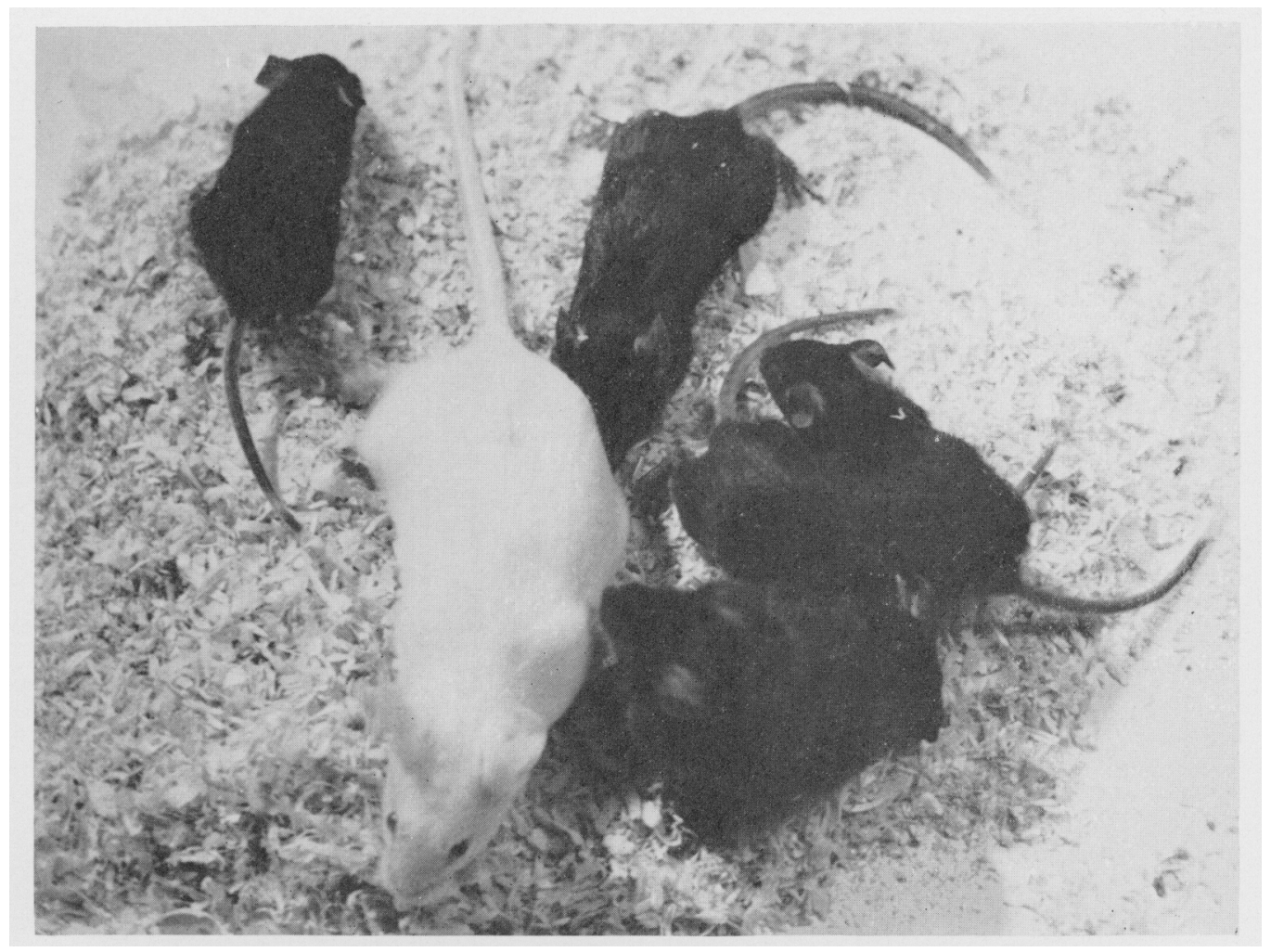

FIG. 2. Litter of five C57BL/6J mice born to an albino mother (CFLP) who received six

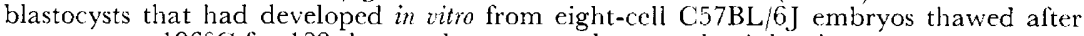
storage at $-196^{\circ} \mathrm{C}$ for 189 days and transported across the Atlantic. 
pseudopregnant female and four normal melanin-free fetuses were recovered at autopsy on the 18th day of pseudopregnancy (Table 1). Thus, a total of thirteen C57BL $/ 6 \mathrm{~J}$ embryos $(50 \%$ of those originally frozen) developed to full term fetuses and live young and four BALB/cWt $(40 \%)$ survived to full term fetuses after storage for 222 days at $-196^{\circ} \mathrm{C}$. Overall, significantly more C57BL $/ 6 \mathrm{~J}$ than $\mathrm{BALB} / \mathrm{cWt}$ embryos survived to the blastocyst stage in vitro $\left(\chi_{[1]}^{2}=35.8 ; P<0.001\right)$ but the proportion of embryos recovered after thawing that developed into fetuses and live young was not significantly different $\left(\chi_{[1]}^{2}=0.31\right.$; N.S. $)$

We have demonstrated for the first time that mouse embryos remain viable when stored at $-196^{\circ} \mathrm{C}$ for prolonged periods of time and that, under these conditions, embryos can be successfully transported from country to country. Although the sample sizes were not large, no deterioration in viability was detected during storage for periods up to 8 months. This finding agrees with previous reports for other frozen cells stored for extended periods at $-196^{\circ} \mathrm{C}$ (Meryman, 1966). The induction of mutations and chromosomal abnormalities by background ionizing radiation during low temperature storage cannot be assessed from the present results but these effects are now being investigated.

Compared with the survival of frozen-thawed spermatozoa and other frozen cells, the survival rate of mouse embryos is extremely high. Several advantages accrue from this technique. Given optimal conditions for freezing, thawing and embryo transfer, the successful long-term storage of all mutant and inbred strains of mice would seem to be possible. Genetic pedigree standards can now be established for all inbred strains and these used to check for genetic drift. Frozen embryos can be easily transported between countries and this means that colonies of mice affected by disease or other hazards, e.g. fire, could be quickly re-established from frozen stocks of embryos.

This work has been supported by a grant from the Medical Research Council, U.K. (D.G.W.) and from NIH Research Grants, U.S.A. (W.K.W.). During part of this investigation D.G.W. was a recipient of a Beit Memorial Fellowship, and thanks Dr Earl Green, Director of the Jackson Laboratory, for providing accommodation during the summer of 1972 .

\section{REFERENCES}

Biggers, J. D., Moore, B. D. \& Whittingham, D. G. (1965) Development of mouse embryos in vivo after cultivation from two-cell ova to blastocysts in vitro. Nature, Lond. 206, 732.

Meryman, H. T., Ed. (1966) Cryobiology. Academic Press, New York \& London.

Whittingham, D. G. (1971a) Survival of mouse embryos after freezing and thawing. Nature, Lond. 233, 125.

Whittingham, D. G. (1971b) Culture of mouse ova. 7. Reprod. Fert., Suppl. 14, 7.

Whittingham, D. G., Leibo, S. P. \& Mazur, P. (1972) Survival of mouse embryos frozen to $-196^{\circ} \mathrm{C}$ and $-269^{\circ} \mathrm{C}$. Science, N.Y. 178, 411 .

Whittingham, D. G. \& Wales, R. G. (1969) Storage of two-cell mouse embryos in vitro. Aust. 7. biol. Sci. 22, 1065.

WILMUT, I. (1972) The effect of cooling rate, warming rate, cryoprotective agent and stage of development on survival of mouse embryos during freezing and thawing. Life Sci. 11, 1071. 